\title{
Grass-Fed Milk Perception: Profiling Italian Consumer
}

\author{
Giovanni Peira ${ }^{1,2, *} \mathbb{C}$, Damiano Cortese ${ }^{3}$, Giampiero Lombardi ${ }^{2,4} \mathbb{D}$ and Luigi Bollani 5 \\ 1 Department of Management, University of Torino, Corso Unione Sovietica, 218bis, 10134 Torino, Italy \\ 2 NatRisk, Research Centre on Natural Risks in Mountain and Hilly Environments, University of Torino, \\ Corso Unione Sovietica, 218bis, 10134 Torino, Italy; giampiero.lombardi@unito.it \\ 3 Department of Foreign Languages, Literatures and Modern Cultures University of Torino, \\ Via GiuseppeVerdi, fronte n. 41, Complesso Aldo Moro, 10124 Torino, Italy; damiano.cortese@unito.it \\ 4 Department of Agricultural, Forest and Food Sciences, University of Torino, Largo Paolo Braccini 2, \\ Grugliasco, 10095 Torino, Italy \\ 5 Department of Economic, Social, Mathematical and Statistical Science, Corso Unione Sovietica, 218bis, \\ 10134 Torino, Italy; luigi.bollani@unito.it \\ * Correspondence: giovanni.peira@unito.it
}

Received: 19 November 2020; Accepted: 9 December 2020; Published: 11 December 2020

\begin{abstract}
This paper aims at analyzing the consumers' perception of grass-fed milk so as to understand if a production based on a sustainable business model could represent a response to new and emerging needs in consumption. The sample of the study was constituted by a total of 750 Italian members of the International Association Slow Food. A Principal Component Analysis (PCA) was used to summarize the quantitative variables, which, grouped in "dimensions", were used as input for multivariate statistics (HCA, MCA) in order to define and explain consumer profiles. Our data confirm an in-progress change in milk consumption: Consumers were more oriented towards quality, local supply chains, traceability, and are characterized by an increasing propensity to a higher expense for grass-fed milk. Further research will enlarge the proposed panorama covering a sample of more general consumers. The study was a preliminary market analysis that could be used as the basis for a production, distribution, and consumption chain grass-fed-based model. Grass-fed milk is a product linking individual and societal needs for more sustainable production and entrepreneurship that creates a higher value product aligned with market needs.
\end{abstract}

Keywords: milk; grass-fed milk; pasture-raised milk; grass-fed; dairy farms; consumer behavior; consumption; milk market; quality milk; sustainability; value creation

\section{Introduction}

Globalization has led to more uniform and convergent food production and consumption models due to innovation and market globalization. This phenomenon allowed changes in economy and production, as well as a cultural convergence throughout the world. On the one hand, the consumers' needs have been standardized with a consequent disappearance of traditional differences in taste. On the other hand, food companies are now more skilled in meeting the demand created by large-scale production. Indeed, one of the biggest risks involved in globalization is excessive cultural standardization, known as the loss of individual cultural identity, behavior, and choice. However, as a reaction to globalization, there is also a tendency in some food sectors to adopt alternative approaches to both food production and consumption that will become even more evident in the near future [1-3]. In fact, some people are changing the consumption paradigm by adopting a style focused on good practices, such as choosing goods with a special taste or healthy food, and orientating towards cultures of the past, naturalness, local and regional food, animal welfare, and sustainability. 
Guaranteeing widespread and sustainable well-being by preserving and improving environmental, social, cultural resources and heritage is one of the objectives set by these tendencies [4-6].

In Italy, changes in production and consumption patterns must be contextualized with the socio-demography of the last seventy years. Indeed, the concentration of the population in urban areas because of the abandonment of mountain areas has brought several economic, environmental, and social impacts. Faced with the complexity of the contemporary challenges, in the last twenty years, a situation of profound divergence has been determined within the Alpine mountain areas. On the one hand, mountain areas have implemented non-sustainable development models characterized by intensive territorial exploitation. On the other hand, there is a partial rediscovery of the marginal areas where the implementation of sustainable development models is favored [7-9]. The Common Agricultural Policy (CAP) of the European Union has provided for financial measures to support the agriculture of these disadvantaged areas, but the results obtained are not yet satisfactory. Therefore, it is necessary to recover mountain agriculture also with more adequate promotion of foodstuffs to improve the competitiveness of farms located in the mountains. Among the different mountain farming systems able to provide such foodstuffs, dairy cow systems with hay and pasture-fed animals could potentially offer good profitability to farmers [10].

Milk is generally considered a commodity such as cereals and sugar. Its price depends largely on the quantity, while only in a small proportion it is determined by quality parameters (i.e., fat, proteins, bacteria load, and somatic cells) and origin. However, when ruminants are fed hay and fresh herbage, mainly at pasture, milk has a different chemical, nutritional and nutraceutical composition than does 'conventional' grain-fed milk [11], so that distinguishing between the two types of milk becomes possible and the former can be labeled as grass-fed milk.

The terms "grass-fed", "grass-raised", and "pasture-raised" have been broadly used in Europe and the U.S.A. to define not only milk, but also meat from ruminants predominantly fed forages from high-biodiversity grasslands. Grass-fed milk is mainly gathered from small family farms using extensive production methods oriented to animal welfare [12-14], which have a lower environmental impact compared to the more conventional ones. Moreover, since supporting grass-fed milk maintains milk production in areas and regions that are at risk of depopulation, it also generates a positive social impact [15]. In addition, further connected supply chains would be activated, for instance, food and wine tourism that represents a response "in fighting economic decline and unemployment" [16,17]. In this context, a new sustainable business model could grow and speed up to solve the twofold risk of depopulation of marginalized-including mountain —areas and of considering food-milk in particular-as a commodity instead of a common good [18,19].

On the producers' side, the availability to adopt such a model has increased during last years, pushed by the need to differentiate productions and overcome the difficulties of the milk market for direct consumption due to the reduction in milk price from 2015, when the supplementary levy scheme, better known as the "milk quota" regime [20], was withdrawn.

Scholars have emphasized that consumers are paying more attention to food quality when purchasing foodstuff and that the competition in the food industry is now highly consumer-oriented, involving safety and value creation [21-23]. Furthermore, the competitiveness of a high-quality food product depends on an efficient supply chain governance [24]. Noteworthy is the fact that consumers are more and more oriented to high-quality products and are willing to pay for them. Indeed, the Italian milk-drinking market trends are increasingly orienting supply and demand towards a growing diversification of premium products [25-27], such as organic and food products with the optional quality term "Mountain Product" introduced by EU $[28,29]$. However, although some Italian consumers might be inclined to buy grass-fed milk, the factors driving the choice of milk are mostly unknown. Specifically, how much they knew about grass-fed milk and, whether or not, they might be willing to buy this type of product at a higher price if they were given more information.

This paper aims to deepen the knowledge of a sample of consumers on the choice criteria in the purchase of milk, on how they perceive the grass-fed milk, and whether they might be willing to buy 
this type of product at a higher price if they were satisfactorily informed on its features. Specifically, our purpose was to answer these main research questions: Is grass-fed milk already known among consumers? How does a qualified sample of them perceive it? Can one or more profiles of grass-fed milk potential consumers be outlined and described? What could be the willingness to pay for this milk? Answering such questions would help gather useful information about the potential market generated by a "grass-fed milk" alternative production model.

The structure of the article consists of five paragraphs: Introduction, Methodology, Results, Discussion, and Conclusions.

\section{Methodology}

The research was carried out to identify homogeneous groups of consumers who adopted sustainable behavior in their food purchasing choices. With this purpose, the Slow Food Italy Association in Bra was identified and chosen to collaborate in the research project. This organization is part of the Slow Food network that seeks to protect and promote local products in many countries of the world. Its members have a very conscious approach to food, based on a concept defined by three principles: Good, clean, and fair [30], meaning that not only do they appreciate the quality of food, but they also pay attention to how it is produced, its impact on the environment, and whether producers are paid a fair price. Slow Food consumers were identified as a good target for a premium product, such as grass-fed milk.

A survey was prepared to investigate consumers' milk consumption habits. The following information was collected in the questionnaire: Personal data (i.e., gender, age, family components, occupation, qualification, and residence), information about milk habits (i.e., the type of milk bought, how much it cost, where it was bought, and what influenced choices) and information about how much consumers knew about "grass-fed milk" (after having given the respondents a brief definition of grass-fed milk, the product availability and asking them how much they would be willing to pay for it).

In particular, as regards the aspects that influence consumer choices, a battery of 10 questions was introduced, each based on a 10-point Likert scale, to capture the importance attributed by the consumer to quality, price, relationship between quality and price, brand, origin, local supply chain, traceability, nutrients, fats, information on how the milk must be stored and its shelf life. The use of 10-point Likert scales, compared to parallel choices with seven or five points, is motivated by the ability attributed to Slow Food members to perceive (also dedicating the necessary time) the characteristics of their food choices in a more refined way than for a generic individual: In this case, the result obtained can incorporate greater variability in the expression of the score [31,32]. This allows for a subtler distinction between respondents' opinions and is also more suitable for a subsequent statistical analysis where scores are considered as quantitative characteristics. Furthermore, the 10-point Likert scale is more effective and more familiar as a concept (the "out of ten" rating), especially considering consumers and people not used to different grades [33,34].

A pilot questionnaire was given to 50 Slow Food members at Eataly Torino, the first shop of the main retail company of Italian high-quality foods [35,36]. According to Vecchio and Annunziata and Bonadonna et al., this was developed to evidence any feasible mistake and correct the questionnaire in its final version [37,38]. The research was done in 2018. The survey was sent via email (Google Drive form), with the CAWI (Computer Assisted Web Interview) interview [39-41].

\subsection{Sampling}

The survey was addressed to Slow Food members, who live in three Italian regions: Campania, where the first attempts to promote grass-fed milk were made; Lombardy, Italy, an economically developed area that pays attention to new food proposals; Piedmont, Italy, which has a great potential for grass-fed milk production and that is the region where Slow Food Association was born. A total of 750 replies were collected, involving respondents through the management of the Slow Food Italy Association. 
The main variables that are taken into consideration to identify customer profiles are shown in Table 1, together with the first results, which report the corresponding frequency distributions (Figure 1).

Table 1. Sample distribution of the variables collected with the questionnaires (the different categories of each variable are described in the column "category" using the same labels of Figure 2).

\begin{tabular}{|c|c|c|}
\hline Variable & Category & Distribution per Type \\
\hline \multirow{3}{*}{ Residence } & Piedmont & $35.60 \%$ \\
\hline & Lombardy & $52.53 \%$ \\
\hline & Campania & $11.87 \%$ \\
\hline \multirow{2}{*}{ Gender } & Male & $57.20 \%$ \\
\hline & Female & $42.80 \%$ \\
\hline \multirow{3}{*}{ Education level } & Middle School & $4.40 \%$ \\
\hline & High School & $40.40 \%$ \\
\hline & Degree & $55.20 \%$ \\
\hline \multirow{5}{*}{ Age } & 18-24 (Age_18-24) & $6.67 \%$ \\
\hline & 25-34 (Age_25-34) & $17.20 \%$ \\
\hline & 35-44 (Age_35-44) & $16.67 \%$ \\
\hline & 45-64 (Age_45-64) & $48.13 \%$ \\
\hline & $>65$ (Age_65+) & $11.33 \%$ \\
\hline \multirow{11}{*}{ Employment } & Freelancer & $18.53 \%$ \\
\hline & Dealer & $3.07 \%$ \\
\hline & Manager & $8.40 \%$ \\
\hline & Employee & $31.87 \%$ \\
\hline & Teacher & $4.67 \%$ \\
\hline & Blue-Collar & $2.27 \%$ \\
\hline & Student & $5.20 \%$ \\
\hline & Working student & $2.53 \%$ \\
\hline & Housewife & $1.60 \%$ \\
\hline & Retired & $13.60 \%$ \\
\hline & Other Employment & $8.27 \%$ \\
\hline \multirow{5}{*}{ Members of each family unit } & 1 (Fam Memb_1) & $10.67 \%$ \\
\hline & 2 (Fam Memb_2) & $35.47 \%$ \\
\hline & 3 (Fam Memb_3) & $24.40 \%$ \\
\hline & 4 (Fam Memb_4) & $23.47 \%$ \\
\hline & $>4$ (Fam Memb_gt.4) & $6.00 \%$ \\
\hline \multirow{5}{*}{$\begin{array}{l}\text { Frequency of milk consumption } \\
\qquad(\mathrm{fmc})\end{array}$} & daily (Fmc_Daily) & $56.27 \%$ \\
\hline & once a week (Fmc_Weekly) & $14.93 \%$ \\
\hline & occasional (Fmc_Rarely) & $11.20 \%$ \\
\hline & almost never (Fmc_AlmostNever) & $14.67 \%$ \\
\hline & never (Fmc_Never) & $2.93 \%$ \\
\hline \multirow{4}{*}{ Amount of milk per week (in liters) } & $<1$ (Litres_lt.1) & $34.27 \%$ \\
\hline & 1-3 (Litres_1-3) & $42.53 \%$ \\
\hline & 3-5 (Litres_3-5) & $16.53 \%$ \\
\hline & $>5$ (Litres_gt.5) & $6.67 \%$ \\
\hline \multirow{2}{*}{ Knowledge of grass-fed milk (gfm) } & Never heard about grass-fed milk (Gfm_UnKnown) & $71.20 \%$ \\
\hline & Already heard about grass-fed milk (Gfm_Known) & $28.80 \%$ \\
\hline \multirow{2}{*}{$\begin{array}{l}\text { Prospected buying frequency of } \\
\text { grass-fed milk }\end{array}$} & frequent (Hp_Usually) & $66.13 \%$ \\
\hline & occasional (Hp_Rarely) & $33.87 \%$ \\
\hline \multirow{4}{*}{$\begin{array}{l}\text { Price (per liter) (ppl) that the } \\
\text { consumer would be willing to pay }\end{array}$} & $<1.5$ Euros (Price_lt.1.5) & $2.53 \%$ \\
\hline & 1.5-2 Euros (Price_1.5-2) & $38.80 \%$ \\
\hline & 2 Euros (Price_2) & $36.13 \%$ \\
\hline & $>2$ Euros (Price_gt.2) & $22.53 \%$ \\
\hline
\end{tabular}




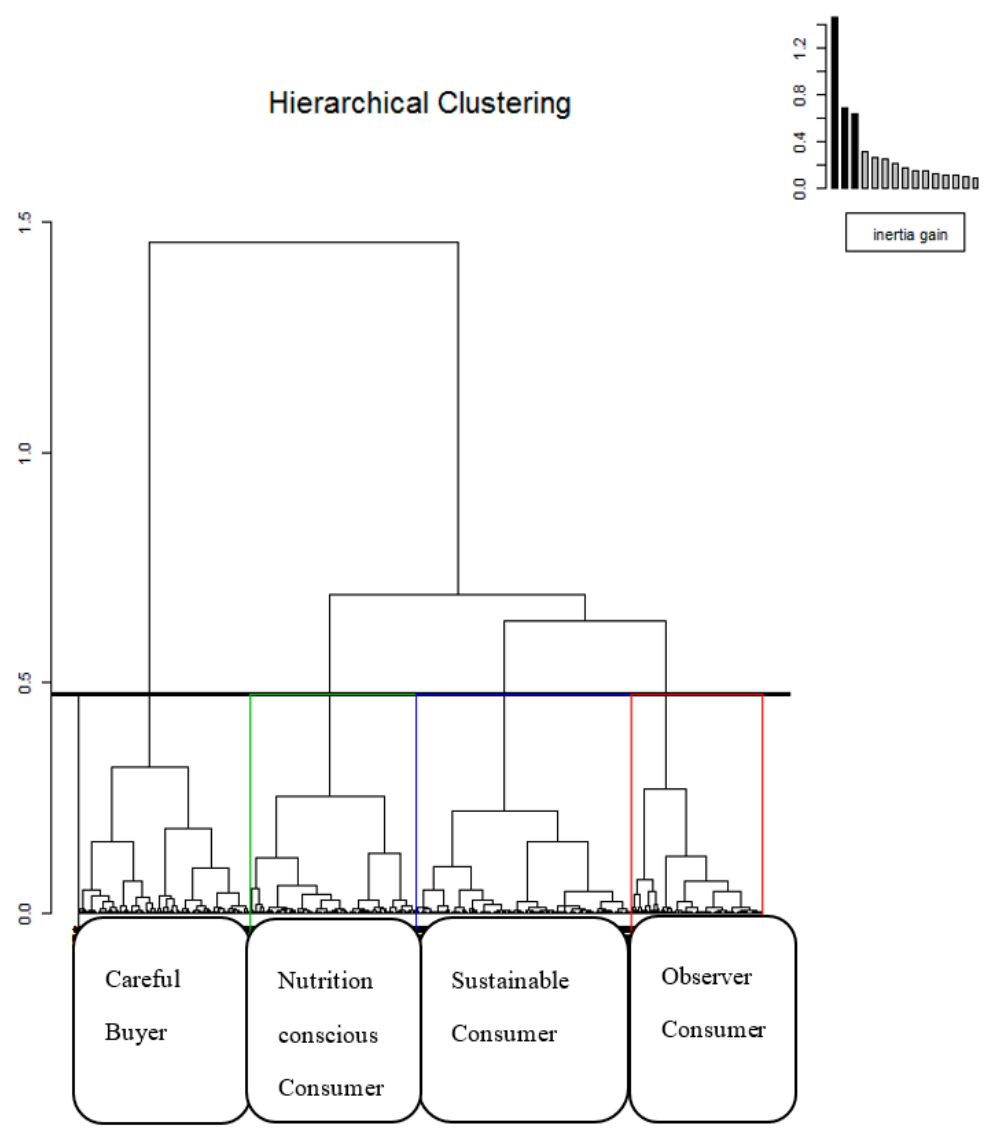

Figure 1. Dendrogram of the Hierarchical Cluster Analysis (HCA) applied on the first five Principal Component Analysis' (PCA's) factorial dimensions.

\subsection{Statistical Analyses}

Data were explored with descriptive statistics, followed by multivariate statistical techniques to get an integrated vision of the relationships among the variables.

Given the high number of collected variables, a Principal Component Analysis (PCA) was carried out on the set of ten variables corresponding to the above questions, posed in Likert form, regarding influencing factors for their choices.

The first five PCA dimensions, which gave a solid structure of the correlations amongst the data, were then used as input for a Hierarchical Cluster Analysis (HCA), using squared Euclidean distance as a similarity measure and Ward method to group consumers by response affinity. These clusters were then considered levels of a qualitative variable. Multiple Correspondence Analysis (MCA) was then used to consider the main qualitative variables of the questionnaire as a whole, including cluster membership from the previous analysis. MCA is a technique used to detect and represent underlying structures in a dataset made-up of qualitative variables. Milk consumption, hypothetical buying frequency, knowledge of grass-fed milk, the price the consumer would be willing to pay for it, the amount of milk drunk per week (in liters), were used as active variables for computing the factorial plane. Employment, education level, age, gender, residence, and family unit supplied supplementary information and were used as illustrative variables. R software, FactoMineR [42] and CA [43] packages were used for the analyses.

\section{Results}

The distribution amongst the categories of each variable describing the interviewees is reported in Table 1 . The sample included $57 \%$ males and $43 \%$ females. Most of the respondents were employees, followed by freelancers and retired persons. Half of the sample had a degree, followed by those with 
high school education and then lower education. Milk was drunk daily by $56 \%$ of the respondents and a small percentage of families consumed more than 3 L per week. Only $29 \%$ already had some knowledge of grass-fed milk. A total of $66 \%$ said they would be willing to buy it frequently, to pay an additional amount for it compared to conventional milk and that they considered a price of two Euros per liter or more acceptable (Table 1).

On the basis of the responses (expressed in Likert scale) to questions concerning quality, price, price and quality ratio, brand, origin, local supply chain, traceability, nutrients, fats, and information on how the milk is to be stored and shelf-life, respondents were grouped into four clusters (Figure 1), corresponding to four consumer profiles:

1. Careful Buyer (26\% of the sample), which included consumers who were very interested in price, price/quality ratio, quite interested in brand and had a low interest in the local supply chain and/or traceability;

2. Observer (24\%) that included consumers who make decisions based on price, price/quality ratio, and also on the local supply chain and traceability;

3. Nutrition conscious (19\%), which included consumers interested in nutrients, fats, and storage data;

4. Sustainable (31\%) that included consumers very interested in the local supply chain and traceability and quite interested in the brand, but not in price and/or the price/quality ratio.

The results of the Multiple Correspondence Analysis performed using all the variables in Table 1 and the cluster membership obtained from the HCA are plotted in Figure 2. Apparently, the horizontal axis in both charts explained a low percentage of inertia. However, due to MCA coding scheme, the inertia of the solution space was artificially inflated and, therefore, the percentage of inertia explained by the first dimension was underestimated [44]. The percentage of explained variance of the first two factors, re-evaluated according to Benzecri [45] increased up to $77.94 \%$ for the first dimension and $14.70 \%$ for the second one. By applying Greenacre method [43], a more parsimonious method, $57.95 \%$ and $10.93 \%$ were obtained for the first two dimensions, respectively. Considering the sum of the percentages of the variance explained by the first two factors, both methods provided a good representation, accounting for $92.64 \%$ and $68.88 \%$, respectively. The position of the items of the same variable along the horizontal axis (Figure 2a), revealed that this axis is related to the frequency of milk consumption, the amount of milk drunk per week (in liters), and the prospected buying frequency of grass-fed milk. The values of these three variables are in ascending order, from right to left (here, for the frequency of milk consumption, a single position is considered for the categories "never", "almost never", and "rarely", which are all in an area of the graph more on the right side than the remaining categories). The vertical axis shows the distribution of the four clusters of milk consumers from top to bottom (Careful Buyer, Observer, Nutrition conscious, and Sustainable, which seemed to follow a trend in line with an ascending education level of the respondents (Figure $2 b$ ).

The Careful Buyers were distributed at the top, i.e., they were quite interested in price and price/quality ratios. Indeed, they were willing to pay a little more for grass-fed milk. Moreover, we could assume that this cluster had large family units that probably need to buy quite a lot of milk each week, but also young people, mostly students and housewives (Figure 2b).

The average consumer, classified as Observer (Figure 2a), was a very neutral buyer compared to other consumers. This group included several types of employees, such as blue-collar workers, white-collar workers, retired persons, working students, etc., who had an average education level (Figure 2b).

The Nutrition-conscious consumer, as the name evokes, was very interested in nutrients, especially fats and how the milk is stored. He generally drinks milk regularly throughout the week (Figure 2a). This cluster included freelancers, managers, dealers, teachers, and others with a medium-high education level, such as a diploma/degree (Figure $2 b$ ). This category was halfway between people who know about grass-fed milk and those who do not, who would pay a moderate extra sum for it (Figure 2a). 


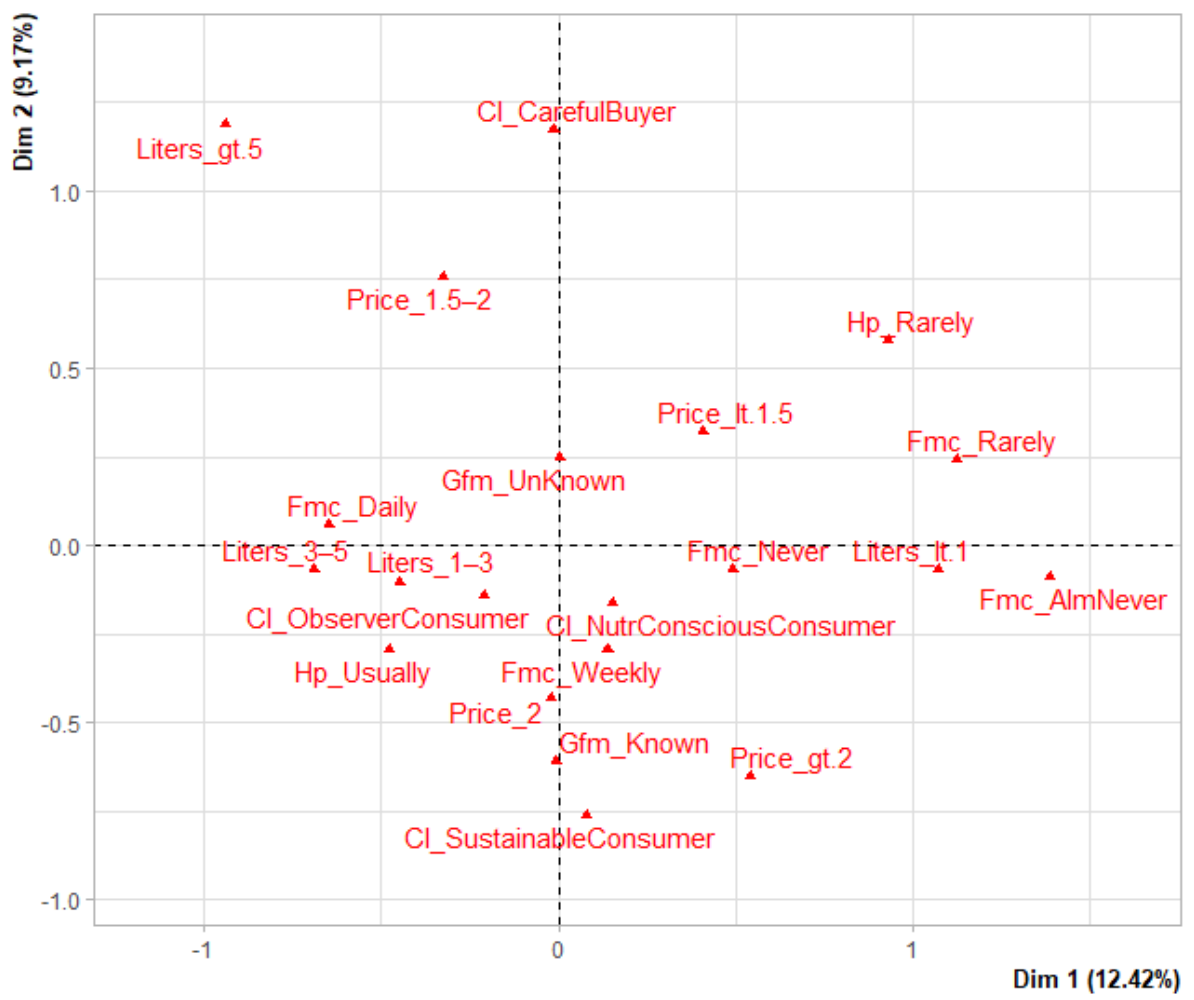

(a)

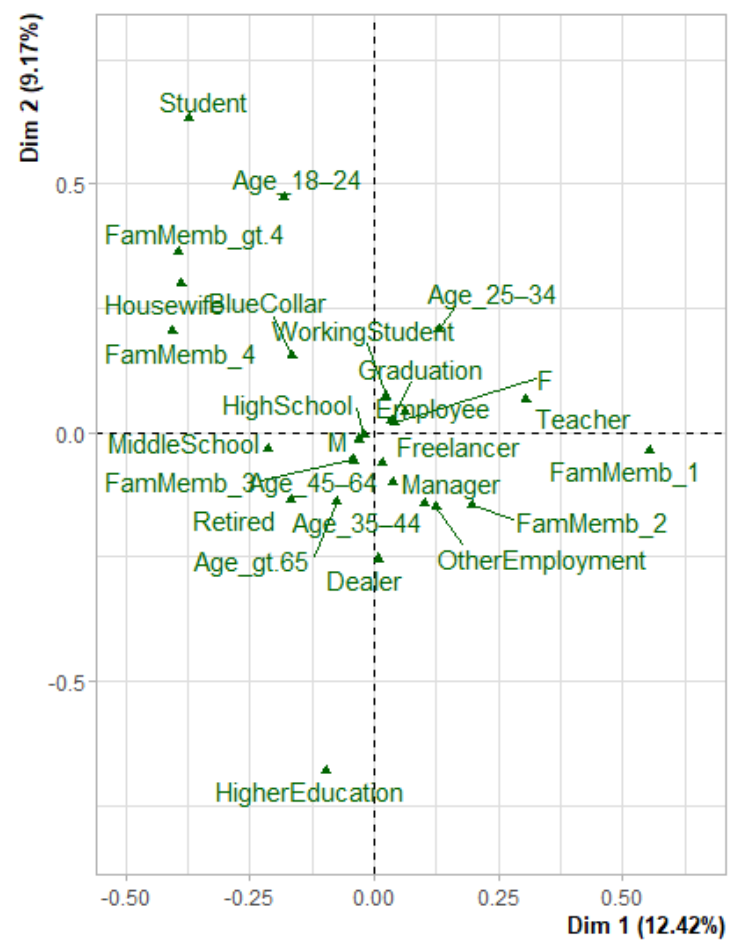

(b)

Figure 2. (a) Principal plane of the Multiple Correspondence Analysis (MCA) determined by the first two dimensions, showing the projections of the items included in the active variables, i.e., those used to identify the position of the plane. (b) The figure shows the same plane, with illustrative variables projected on it (these variables are not used to identify the plan but projected once having determined it). Single variables and items are displayed with the same codes as Table 1. 
The last cluster included the so-called Sustainable consumer. Most of the people in this category had a high education (Figure 2b) and had already heard about grass-fed milk (Figure 2a). Their answers showed that they were willing to pay quite a high price for grass-fed milk and drink it regularly (Figure 2a). This may be determined by their interest, not only in quality and social impact in terms of traceability but also in having a local supply chain.

\section{Discussion}

The results of the analysis aimed at answering the first research question, i.e., whether a qualified sample of consumers already knew the grass-fed milk, clearly show that the knowledge of this product was scarce, in spite of their qualification, even though they were able to recognize an increased qualitative and economic value compared to a standard conventional product

Regarding the second research question on how grass-fed milk is perceived, the main results of our research confirm the trends of other studies, such as that carried out by Stampa et al. [28] who made the first systematic review on perceptions, preferences, behavior of consumers on the theme of grass-fed milk. The review showed that consumers are very sensitive to sustainability and health issues. Studies carried out by Kühl et al. and Conner and Getter highlighted that grass-fed products are becoming more widespread in some consumer segments, both in Europe and the U.S.A. markets [46,47]. Indeed, it was observed that not only the Sustainable cluster members were interested in the socioeconomic and environmental aspects but also the other clusters were slowly but surely creeping in this direction [48-51]. Among the dimensions of sustainability, the ethical one has been increasingly affecting consumers, especially animal welfare [52].

Concerning the willingness to pay (third research question), although $59 \%$ of the sample declared themselves willing to pay a price of two euros or more for the purchase of quality milk (compared to an average of about 1.55 euros for conventional milk), some factors, such as gender, age, and motivation, strongly influenced this choice. Indeed, as noted elsewhere, those who take into account a healthy dietary lifestyle and/or pay attention to the way the animals are bred and kept were likely to accept a higher price for a quality product [52]. Therefore, they were the main target for grass-fed milk producers, followed by those who are less attentive to these issues, who still remain somewhat of a challenge [53]. Consumers' willingness to pay depended on the level of income and the information provided to the customer [54,55].

Moreover, it was observed that the "sustainable" consumers had a higher inclination to spend more on grass-fed milk than the other clusters. Indeed, one-third of the sample was willing to pay up to $30 \%$ more for grass-fed milk than for conventional fresh milk available from large-scale retailers. These consumer attitudes and the estimations of how much they would be willing to pay confirm the expectancy value of grass-fed milk as organic milk and another premium foodstuff [56-60].

Among the consumer clusters also emerged in our study, more and more attention was paid to the health benefits of products, and pasture-raised milk might have some of them. It has been scientifically proven that, compared with conventional milk, the grass-fed one contains numerous nutrients that have positive health benefits, such as conjugated linoleic acid (CLA), polyunsaturated fatty acids of the omega-3, and more omega-3 series fatty acids per se, and antioxidant molecules, such as the vitamins $\mathrm{E}$ and A [61-65]. In fact, even if this aspect seems to be innovative, it is actually a return to the values of old, known by our grandparents, which are not present in the commonly marketed milk obtained from grain-fed cows [66].

After all, the links between food and risk of disease and between the product and the history and culture of the territory of origin play an important role. Grass-fed milk evokes an image of naturalness in the consumers' mind, a rediscovery of tradition, and a deep link with the territory as for the other products in the mountain area. Terms like "mountain milk" or "grass-fed milk" are becoming commonplace and the term Mountain Product has finally been regulated by the EU [67-70].

Many consumers pay more and more attention in their purchasing process to product labeling and certifications [71-73]. There is, therefore, an interesting propensity to provide-through the 
proposed model of grass-fed milk-an answer to risks, challenges and opportunities of marginal areas, in which models more attentive to sustainability, ethics, and socio-environmental danger containment are desirable. The clusters showed these tendencies in subjects with an average age of 40 years, that had a medium/high scholastic education and, it may be assumed, a certain degree of spending freedom. It may be hypothesized that these sustainability concepts will spread to the "new generations" and suppliers of all types of consumer goods will have to meet the requisites these "new generations" are looking for. Indeed, eating is no longer, for many, just a way to survive, but is rather an experience to be enjoyed within a more complex sphere of issues, which includes, to name but a few, the history behind the product, its organoleptic and nutritional qualities, that go hand in hand with multiple ethical questions [74-76].

The results of this study want, on the one hand, to enrich the academic debate on the topic of the high quality of such a particular product and, on the other hand, to offer dairy companies greater knowledge of the consumer.

\section{Conclusions and Perspectives}

The Slow Food consumers selected for this research were identified as a good target for premium products, such as grass-fed milk. However, data showed that the grass-fed milk was mostly unknown among them. Likely, well-defined communication and marketing strategies have to be identified for such a product to be successful in the markets. The organization of a grass-fed milk supply chain and an appropriate promotion would be the first steps to encourage consumer demand.

Even though consumers split into different clusters show different attitudes towards the grass-fed milk, the members of some clusters (Sustainable and Nutritious conscious) had a good propensity to purchase the milk regularly and spend more than for conventional milk after they were informed about the milk nutritional benefits and the differences from conventional milk from cows generally fed corn silage and concentrates.

Grass-fed milk chain could represent a new sustainable, competitive, and replicable business model, which, moreover, fully responds to the European Green Deal Policy [77-82]. The development of business models above all in mountain area overcomes the anachronistic concept of mountains as a place of lost naturalness, heritage, and of an exclusive archaic and not competitive economy, and in some way, opposed to the city $[83,84]$. Moreover, the limited accessibility and reduced anthropization of mountain areas represent favorable conditions for the accumulation of natural capital in terms of biocapacity (agricultural, forest, and pasture) and landscape capital, which represent the factors of true specialization of the mountain compared to the plain and the hill. This scenario could help the development of economic activities, such as tourism [85].

From the farmers' point of view, grass-fed milk model should not be perceived as a panacea for the Italian milk sector that solves most of its issues. The market liberalization is bringing consistent economic opportunities and potential advantages on the one hand. On the other hand, such change is bringing new issues and difficulties because of the increasing complexity, market dimension, stakeholder relationships. Though grass-fed milk is not the way to solve the problems of the sector, it could be an achievable way. In recent years, the milk market has been gradually enriched with new products. Over and above fresh pasteurized milk and UHT milk, the consumer can choose a wide range of milk, also depending on their experiential path.

The findings presented in this paper have limitations resulting from the sample of consumers whose answers were analyzed, who were all members of Slow Food association, known to have a very conscious approach to food. In the future, the research should be extended to a larger sample of consumers representative of the Italian population. Despite limitations, our results show good perspectives for the implementation of grass-fed milk business model, whose potential success could depend on what such a milk is: Not a novel food, but rather a new concept. This milk belongs to the tradition of the Italian dairy sector, produced by small-sized farms, mainly located in the mountain area, where animals are fed with high-biodiversity fodders. The innovative nature of the concept was 
stated and reinforced by Carlo Petrini, founder of Slow Food. Interviewed by authors, he said that "the added value of a product is based on good practices [ ... ]. We need to focus on milk, to reconstruct its appeal and re-propose in our cities the dairy as a traditional milk shop with a modern look: A hub gathering local gastronomic excellences".

Author Contributions: G.P., D.C., G.L. and L.B. contributed fully and equally to this work. All authors have read and agreed to the published version of the manuscript.

Funding: This research received no external funding.

Acknowledgments: The authors thank Barbara Wade from Turin University for her linguistic advice.

Conflicts of Interest: The authors declare no conflict of interest.

\section{References}

1. Galli, F.; Favilli, E.; D'Amico, S.; Brunori, G. A Transition towards Sustainable Food Systems in Europe Food Policy Blue Print Scoping Study; Food Policy Blue Print Scoping Study; Laboratorio di Studi Rurali Sismondi: Pisa, Italy, 2018.

2. Agrillo, C.; Milano, S.; Roveglia, P.; Scaffidi, C. Slow Food's Contribution to the Debate on the Sustainability of the Food System. Available online: https:/www.slowfood.com/sloweurope/wp-content/uploads/INGfood-sust.pdf (accessed on 10 November 2019).

3. Barilla Eating in 2030: Trends and Perspectives-BCFN Foundation. Available online: https://www.barillacfn. com/en/publications/eating-in-2030-trends-and-perspectives/ (accessed on 25 March 2020).

4. Elkington, J. Towards the Sustainable Corporation: Win-Win-Win Business Strategies for Sustainable Development. Calif. Manag. Rev. 1994, 36, 90-100. [CrossRef]

5. Elkington, J. Enter the triple bottom line. In The Triple Bottom Line: Does it All Add Up; Henriques, A., Richardson, J., Eds.; Routledge: London, UK, 2013; pp. 23-38.

6. Cruz, J.M.; Matsypura, D. Supply chain networks with corporate social responsibility through integrated environmental decision-making. Int. J. Prod. Res. 2009, 47, 621-648. [CrossRef]

7. Dematteis, G. Rapporto Montagne-Italia 2017; Rubettino Editore: Soveria Mannelli, Italy, 2018.

8. IREALP. Montagna: Territorio di Valore. Ridefinire il Concetto di Montanità; IREALP: Milano, Italy, 2008.

9. Tempesta, T.; Vecchiato, D. An analysis of the territorial factors affecting milk purchase in Italy. Food Qual. Prefer. 2013, 27, 35-43. [CrossRef]

10. Swinnen, J. The Political Economy of the 2014-2020 Common Agricultural Policy. An Imperfect Storm; Centre for European Policy Studies (CEPS), Rowman \& Littlefield: Brussels, Belgium, 2015.

11. Lombardi, G.; Peira, G.; Cortese, D. The supply chains of cow grass-fed milk. In Milk-Based Beverages: Volume 9, The Science of Beverages; Woodhead Publishing: Duxford, UK, 2019; pp. 297-330. [CrossRef]

12. Spiertz, J.; Ewert, F. Crop production and resource use to meet the growing demand for food, feed and fuel: Opportunities and constraints. NJAS Wagening. J. Life Sci. 2009, 56, 281-300. [CrossRef]

13. Forbord, M.; Vik, J. Food, farmers, and the future: Investigating prospects of increased food production within a national context. Land Use Policy 2017, 67, 546-557. [CrossRef]

14. Galloway, G.; Conradie, B.; Prozesky, H.; Esler, K. Are private and social goals aligned in pasture-based dairy production? J. Clean. Prod. 2018, 175, 402-408. [CrossRef]

15. Lombardi, G.; Peira, G.; Cortese, D. Strategie per la Valorizzazione Commerciale del Latte Nobile Piemontese; Edizioni DISAFA Dipartimento di Scienze Agrarie, Forestali e Alimentari, Universitá degli Studi di Torino: Turin, Italy, 2016; pp. 1-156.

16. Cortese, D. L'azienda Turistica: Nuovi Scenari e Modelli Evolutivi; Giappichelli Editore: Torino, Italy, 2018.

17. European Commission. Growth, Sectors, Tourism. Available online: https://ec.europa.eu/growth/sectors/ tourism_en (accessed on 25 August 2020).

18. Crescimanno, A.; Ferlaino, F.; Rota, F.S. Classificazione della Marginalità dei Piccoli Comuni del Piemonte; IRES: Turin, Italy, 2008.

19. Vivero-Pol, J.L. The idea of food as commons or commodity in academia. A systematic review of English scholarly texts. J. Rural Stud. 2017, 53, 182-201. [CrossRef]

20. European Commission. Milk Market Situation. Brussels, 24 January 2019. Available online: https:/ec. europa.eu/agriculture/sites/agriculture/files/market-observatory/milk/pdf/market-situation-slides_en.pdf (accessed on 1 October 2020). 
21. Van Rijswijk, W.; Frewer, L.J. Consumer perceptions of food quality and safety and their relation to traceability. Brit. Food J. 2008, 110, 1034-1046. [CrossRef]

22. Mascarello, G.; Pinto, A.; Parise, N.; Crovato, S.; Ravarotto, L. The perception of food quality. Profiling Italian consumers. Appetite 2015, 89, 175-182. [CrossRef]

23. Bonadonna, A.; Alfiero, S.; Cane, M.; Gheribi, E. Eating hamburgers slowly and sustainably: The fast food market in North-West Italy. Agriculture 2019, 9, 77. [CrossRef]

24. López-Bayón, S.; González-Díaz, M.; Solís-Rodríguez, V.; Fernández-Barcala, M. Governance decisions in the supply chain and quality performance: The synergistic effect of geographical indications and ownership structure. Int. J. Prod. Econ. 2018, 197, 1-12. [CrossRef]

25. Bhatt, S.; Ye, H.; Deutsch, J.; Ayaz, H.; Suri, R. Consumers' willingness to pay for upcycled food. Food Qual. Pref. 2020, 86, 104035. [CrossRef]

26. Canavari, M.; Coderoni, S. Consumer stated preferences for dairy products with carbon footprint labels in Italy. Agric. Food Econ. 2020, 8, 4. [CrossRef]

27. Britwum, K.; Bernard, J.C.; Albrecht, S.E. Does importance influence confidence in organic food attributes? Food Qual. Pref. 2020, 87, 104056. [CrossRef]

28. Stampa, E.; Shipmann-Schwarze, C.; Hamm, U. Consumer perception, preferences, and behavior regarding pasture-raised livestock products. A review. Food Qual. Pref. 2020, 82, 103872. [CrossRef]

29. Bentivoglio, D.; Bucci, G.; Staffolani, G. Valorizzazione del latte «Prodotto di montagna»: Un'analisi esplorativa sulle scelte di acquisto dei consumatori. Ital. Rev. Agric. Econ. 2020, 75, 77-88. [CrossRef]

30. Petrini, C. Slow Food: Le Ragioni del Gusto; Laterza \& Figli Spa: Rome, Italy, 2012.

31. Wittink, D.R.; Bayer, L.R. The Measurement Imperative. Mark. Res. 1994, 6, 14-22.

32. Darbyshire, P.; McDonald, H. Choosing Response Scale Labels and Length: Guidance for Researchers and Clients. Australas. J. Mark. Res. 2004, 12, 2.

33. Awang, Z.; Afthanorhan, A.; Mamat, M. The Likert scale analysis using parametric based Structural Equation Modeling (SEM). Comput. Methods Soc. Sci. 2016, 4, 13.

34. Dawes, J. Do data characteristics change according to the number of scale points used? An experiment using 5-point, 7-point and 10-point scales. Int. J. Mark. Res. 2008, 50, 61-104. [CrossRef]

35. Massa, S.; Testa, S. The role of ideology in brand strategy: The case of a food retail company in Italy. Int. J. Retail. Distrib. Manag. 2012, 40, 109-127. [CrossRef]

36. Bertoldi, B.; Giachino, C.; Stupino, M. Innovative approaches to brand value and consumer perception: The Eataly case. J. Cust. Behav. 2015, 14, 353-367. [CrossRef]

37. Vecchio, R.; Annunziata, A. Consumers' attitudes towards sustainable food: A cluster analysis of Italian university students. New Medit. 2013, 12, 47-56.

38. Bonadonna, A.; Peira, G.; Giachino, C.; Molinaro, L. Traditional cheese production and an EU labeling scheme: The Alpine cheese producers' opinion. Agriculture 2017, 7, 65. [CrossRef]

39. De Leeuw, E.D.; Dillman, D.A.; Hox, J.J. Mixed mode surveys: When and why. In International Handbook of Survey Methodology; Hox, J.J., de Leeuw, E.D., Dillman, D., Eds.; Lawrence Erlbaum Associates (LEA): Mahwah, NJ, USA, 2006.

40. Evans, J.R.; Mathur, A. The value of online surveys. Internet Res. 2005, 15, 195-219. [CrossRef]

41. Wright, K.B. Researching internet-based populations: Advantages and disadvantages of online survey research, online questionnaire authoring software packages, and web survey services. J. Comput. Mediat. Comm. 2005, 10, 19. [CrossRef]

42. Escofier, B.; Pagès, J. Analyses Factorielles Simples et Multiples: Objectifs, Méthodes et Interprétation; Dunod: Paris, France, 2005.

43. Greenacre, M. Correspondence Analysis in Practice; Interdisciplinary Statistics Series; Academic Press (Chapman \& Hall/CRC): Boca Raton, FL, USA, 1993.

44. Abdi, H.; Valentin, D. Multiple Correspondence Analysis. Encyclopedia of Measurement and Statistics; Sage: Thousand Oaks, CA, USA, 2007.

45. Benzecri, J.P. Sur le calcul des taux d'inertie dans l'analyse d'un questionnaire. Cah. De L'analyse Des Données 1973, 4, 377-378.

46. Kühl, S.; Gassler, B.; Spiller, A. Labeling strategies to overcome the problem of niche markets for sustainable milk products: The example of grass-raised milk. J. Dairy Sci. 2017, 100, 5082-5096. [CrossRef] 
47. Conner, D.S.; Campbell-Arvai, V.; Hamm, M. Consumer preferences for pasture-raised animal products: Results from Michigan. J. Food Distrib. Res. 2008, 39, 12-25.

48. Vermeir, I.; Verbeke, W. Sustainable Food Consumption: Exploring the Consumer "Attitude-Behavioral Intention" Gap. J. Agric. Environ. Ethic 2006, 19, 169-194. [CrossRef]

49. Sama, C.; Crespo-Cebada, E.; Díaz-Caro, C.; Escribano, M.; Mesías, F.J. Consumer Preferences for Foodstuffs Produced in a Socio-environmentally Responsible Manner: A Threat to Fair Trade Producers? Ecol. Econ. 2018, 150, 290-296. [CrossRef]

50. Annunziata, A.; Mariani, A. Consumer perception of sustainability attributes in organic and local food. Recent Pat. Food Nutr. Agric. 2018, 9, 87-96.

51. Busch, G.; Kühl, S.; Gauly, M. Consumer expectations regarding hay and pasture-raised milk in South Tyrol Austrian. J. Agric. Econ. Rural Stud. 2018, 27, 79-86.

52. De Graaf, S.; Van Loo, E.J.; Bijttebier, J.; Vanhonacker, F.; Lauwers, L.; Tuyttens, F.A.; Verbeke, W. Determinants of consumer intention to purchase animal-friendly milk. J. Dairy Sci. 2016, 99, 8304-8313. [CrossRef] [PubMed]

53. Getter, K.L.; Behe, B.K.; Conner, D.S.; Howard, P.H. Grass-Raised Milk: The Market for a Differentiated Product. J. Food Prod. Mark. 2014, 20, 146-161. [CrossRef]

54. Zhifeng, G.; Schroeder, T. Effects of label information on consumer willingness to pay for food attribute. Am. J. Agric. Econ. 2009, 91, 795-809.

55. Scozzafava, G.; Gerini, F.; Boncinelli, F.; Contini, C.; Marone, E.; Casini, L. Organic milk preference: Is it a matter of information? Appetite 2020, 144, 104477. [CrossRef]

56. Bimbo, F.; Bonanno, A.; Liu, X.; Viscecchia, R. Hedonic analysis of the price of UHT-treated milk in Italy. J. Dairy Sci. 2016, 99, 1095-1102. [CrossRef]

57. Hasselbach, J.L.; Roosen, J. Consumer Heterogeneity in the Willingness to Pay for Local and Organic Food. J. Food Prod. Mark. 2015, 21, 608-625. [CrossRef]

58. Marian, L.; Chrysochou, P.; Krystallis, A.; Thøgersen, J. The role of price as a product attribute in the organic food context: An exploration based on actual purchase data. Food Qual. Pref. 2014, 37, 52-60. [CrossRef]

59. Schröck, R. The organic milk market in Germany is maturing: A demand system analysis of organic and conventional fresh milk segmented by consumer groups. Agribusiness 2012, 28, 274-292. [CrossRef]

60. Wong, J.; Raghunathan, U.; Escalante, C.; Wolfe, K. Consumer premiums for environmentally friendly grass-fed and organic milk in the Southeast. J. Agribus. 2010, 28, 75-88.

61. Simopoulos, A.P. Importance of the omega-6/omega-3 balance in health and disease: Evolutionary aspects of diet. In Healthy Agriculture, Healthy Nutrition, Healthy People; Simopoulos, A.P., Ed.; Karger: Washington, DC, USA, 2011; pp. 10-21.

62. Alothman, M.; Hogan, S.A.; Hennessy, D.; Dillon, P.; Kilcawley, K.N.; O’Donovan, M.; Tobin, J.; Fenelon, M.A.; O'Callaghan, T.F. The "grass-fed" milk story: Understanding the impact of pasture feeding on the composition and quality of bovine milk. Foods 2019, 8, 350. [CrossRef] [PubMed]

63. Cassiday, L. Grass-fed milk: Health or hype? INFORM 2018, 29, 30-32. [CrossRef]

64. Duru, M.; Bastien, D.; Froidmont, E.; Graulet, B.; Gruffat, D. Importance des produits issus de bovins au pâturage sur les apports nutritionnels et la santé du consommateur. Fourrages 2017, 230, 131-140.

65. Visioli, F.; Strata, A. Milk dairy products, and their functional effects in humans: A narrative review of recent evidence. Adv. Nutr. Int. Rev. J. 2014, 5, 131-143. [CrossRef] [PubMed]

66. Lombardi, G.; Probo, M.; Renna, M.; Astegiano, S.; Bellio, A.; Enri Ravetto, S.; Lussiana, C.; Cornale, P.; Malfatto, V.; Mimosi, A.; et al. The Piedmont Noble Milk as a Tool to Improve the Competitiveness of Mountain Farms. J. Nutr. Ecol. Food Res. 2014, 2, 232-236. [CrossRef]

67. Bentivoglio, D.; Giampietri, E.; Finco, A. The new EU innovation policy for farms and SMEs' competitiveness and sustainability: The case of cluster agrifood marche in Italy. Qual. Access Success 2016, 17, 57-63.

68. Bonadonna, A.; Peira, G.; Varese, E. The European Optional Quality Term" Mountain Product": Hypothetical Application in the Production Chain of a Traditional Dairy Product. J. Manag. Syst. 2015, 16, 99-104.

69. Santini, F.; Guri, F.; Paloma, S.G. Labelling of Agricultural and Food Products of Mountain Farming; Publications Office of the European Union: Luxembourg, 2013. [CrossRef]

70. Bollani, L.; Peira, G.; Varese, E.; Nesi, E.; Pairotti, M.B.; Bonadonna, A. Labelling and sustainability in the green food economy: Perception among millennials with a good cultural background. Rivista di Studi Sulla Sostenibilità 2017, 7, 83-101. [CrossRef] 
71. Mitsostergios, K.T.; Skiadas, C.H. Attitudes and Perceptions of Fresh Pasteurized Milk Consumers: A Qualitative and Quantitative Survey. Brit. Food J. 1994, 96, 4-10. [CrossRef]

72. Lanfranchi, M.; Zirilli, A.; Alibrandi, A.; Giannetto, C. Assessment of milk consumer preferences: Identifying the choice factors through the use of a discrete logistic model. Br. Food J. 2017, 119, 2753-2764. [CrossRef]

73. Ding, Y.; Veeman, M.M. Chinese consumers' preferences for quality signals on fresh milk: Brand versus certification. Agribusiness 2019, 35, 593-609. [CrossRef]

74. Alfiero, S.; Christofi, M.; Bonadonna, A. Street food traders, farmers and sustainable practice to reduce food waste in the Italian context. British Food J. 2019, 122, 1361-1380. [CrossRef]

75. Weinrich, R.; Kühl, S.; Zühlsdorf, A.; Spiller, A. Consumer attitudes in Germany towards different dairy housing systems and their implications for the marketing of pasture raised milk. Int. Food Agribus. Manag. Rev. 2014, 17, 205-222.

76. Bollani, L.; Bonadonna, A.; Peira, G. The Millennials' Concept of Sustainability in the Food Sector. Sustainability 2019, 11, 2984. [CrossRef]

77. Sellitto, M.A.; Vial, L.; Viegas, C.V. Critical success factors in Short Food Supply Chains: Case studies with milk and dairy producers from Italy and Brazil. J. Clean. Prod. 2018, 170, 1361-1368. [CrossRef]

78. Lacasa, E.; Santolaya, J.; Millán, I. Study of Sustainable Indicators in a Milk Production Process, World Academy of Science, Engineering and Technology, International Science Index. Ind. Manuf. Eng. 2018, 12, 1558.

79. Corazza, L.; Scagnelli, S.D.; Mio, C. Simulacra and Sustainability Disclosure: Analysis of the Interpretative Models of Creating Shared Value. Corp. Soc. Responsib. Environ. Manag. 2017, 24, 414-434. [CrossRef]

80. Brundtland, G.H. Our common future-Call for action. Environ. Conserv. 1987, 14, 291-294. [CrossRef]

81. European Commission Communication. The European Green Deal. Bruxelles, 19 Dicembre 2019. Available online: https://eur-lex.europa.eu/legal-content/EN/TXT/?qid=1596443911913\&uri=CELEX:52019DC0640\# document2 (accessed on 25 August 2020).

82. European Commission Communication. A farm to fork strategy. Bruxelles, 20 Maggio 2020. Available online: https:/ec.europa.eu/food/sites/food/files/safety/docs/f2f_action-plan_2020_strategy-info_en.pdf (accessed on 25 August 2020).

83. Cerea, G.; Marcantoni, M. La Montagna Perduta. Come la Pianura Ha Condizionato lo Sviluppo Italiano; Franco Angeli: Milan, Italy, 2016; p. 124.

84. Glass, J.; Mc Morran, R.; Price, M.F. The centre for mountain studies contributes to sustainability mountain development at all scales. Mt. Res. Dev. 2013, 33, 103-107. [CrossRef]

85. Genovese, D.; Culasso, F.; Giacosa, E.; Battaglini, L.M. Can Livestock Farming and Tourism Coexist in Mountain Regions? A New Business Model for Sustainability. Sustainability 2017, 9, 11. [CrossRef]

Publisher's Note: MDPI stays neutral with regard to jurisdictional claims in published maps and institutional affiliations.

(C) 2020 by the authors. Licensee MDPI, Basel, Switzerland. This article is an open access article distributed under the terms and conditions of the Creative Commons Attribution (CC BY) license (http://creativecommons.org/licenses/by/4.0/). 